\title{
The Romanian Biogas Sector-Slow Development Despite Attractive Conditions
}

\author{
R. Clodnițchi and A. D. Tanțău
}

\begin{abstract}
Despite the apparent abundance of natural resources, the existence of an attractive support scheme for energy from biogas and a wide-ranging tradition in this field, the Romanian biogas sector underwent a slower development than expected. At the end of 2014 only 10 biogas plants with an installed capacity of 12 MWel (Mega Watt electric) fed electricity into the Romanian national power grid. This study aims to analyse the factors that determined the slow development of the sector. In order to analyse the sector's development so far, we studied the available official data regarding the electricity grid and the implementation of the current and past support mechanisms, statistical data regarding relevant resources as well as the national legislation concerning the support of renewable energy. Further, the available academic literature on the matter was consulted and interviews with several market players in this field were conducted. In order to draft some possible entrepreneurial approaches which could contribute to the future development of the sector which constitutes the secondary goal of our research - we interviewed several market experts using the Delphi method. This article summarizes the findings of the research conducted so far and is meant to help draft appropriate business models for the market situation and contribute to the further development of the sector at a faster pace. Among other findings, the biogas sector is expected to be in future rather connected to the need of own waste neutralization, engaging companies with other core businesses then to generate and sell energy from renewable sources.
\end{abstract}

Index Terms-Biogas, business models, energy markets, potential, Romania.

\section{INTRODUCTION}

The EU's 20/20/20 objective and the EU Directive 2008/98/EC on waste management led to an increase in biogas production in Europe in recent years. To achieve the adopted objectives, several countries have introduced programs to encourage energy production from biogas. Germany, with a percentage of $50.2 \%$ of the European production, is the largest producer of biogas in Europe both in terms of energy generated and energy generated per capita. Great Britain's performance in the field of landfill and sewage gas recovery and purification is also notable. Biogas plants

Manuscript received December 3, 2014; revised May 20, 2015. This work was co-financed by the European Social Fund through Sectoral Operational Programme Human Resources Development 2007-2013; project number POSDRU/159/1.5/S/142115, "Performance and excellence in doctoral and postdoctoral research in Romanian economics science domain."

The authors are with the Faculty of Business Administration in Foreign Languages of the University of Economic Studies Bucharest, 010731 Bucharest, Romania (e-mail: clodnitchi@yahoo.com, adrian.tantau@fabiz.ase.ro). based on agricultural substrate play a less significant role in the UK but still dominate the sector in Germany (80\%). Although Romania has the natural resources and a simulative legal framework for the support of biogas energy production, the sector is still in the fledgling stages of development. Biomass is considered an energy source with great development potential in Romania, not only because of the presence of raw materials, but also due to the fact that the governmental strategy regarding energy stressed its use, especially in CHP-plants and in households.

Given Romania's economic development over the last few years and the country's vast biomass potential, there should be a good chance for a strong biogas sector to develop in Romania. But are there sufficient sources for biodegradable waste in the country which could be suitable for the production of biogas?

A long tradition in the biogas field ranging from $R \& D$ activities in the 70's to the construction of several plants in the 80 's also speaks for a good advance of the sector. If the business environment is favourable in terms of climatic, geographic, managerial terms for the development of biogas energy, what inhibited the development of this particular energy from renewable energy sources (E-RES) field? Why is the entrepreneurial activity level in this sector so low compared to other E-RES sectors? A possible answer to this development could derive from the restrictions on legislative and political levels, which delay the development of renewable energy projects especially for domestic investors with less financial resources than foreign ones, but does the business community agree on this matter? The currently common implemented business models imported from Western Europe in the field might also contribute to the situation. Are there other business models more suitable for the current market conditions in Romania?

In order to gain perspective on the subject we analysed statistical data regarding relevant waste resources, the available official data regarding the electricity grid and the implementation of the current and past support mechanisms, as well as the national legislation concerning the support of renewable energy. Further, the available academic literature on the matter of business models in the biogas field was consulted and open interviews with several market players in this E-RES field from Romania and abroad were conducted 26 experts participated in a 2-stage query using the Delphi method in order to assess the business community's perception on the legal situation as well as the currently implemented and appropriate future business models for the field.

The hypotheses we intend to prove by this academic approach are: 
H1: Romania is characterised not only by a high E-RES production potential from biomass, but also from biogas.

$\mathrm{H} 2$ : The main reason for the slow development of the biogas sector can be explained by political and legal factors.

H3: Current business models in the Romanian biogas sector are not the most suitable for the Romanian market.

\section{DeVElopment OF THE ROMANIAN Biogas SECTOR}

In 2008, one year after the EU-accession, Romania implemented a new support mechanism for electricity generated from RES that covered a wide variety of sources. However, the first modern biogas plant connected to Romania's grid, which produces electricity from landfill gas near Bucharest, was not implemented until 2011. Although some sewage gas plants were previously built, none were connected to the grid. The tradition of using biogas goes far back in Romanian history. Since the 50's research activities for the production of biogas through anaerobic digestion were begun. The research was based mainly on laboratory tests with active methanogenic bacteria, which should produce biogas from various organic substrates.

After 1980, the research and the experiments carried out focused mainly on the use of manure and manure and sewage sludge as substrates for biogas production. In the $80 \mathrm{~s}$, the literature speaks of a biogas produced volume of $85,000 \mathrm{~m}^{3}$ per day alone biogas plants operated newt to sewage treatment plants. In the same time period there were a few biogas plants operated for the treatment of organic waste from the food industry, farms and distilleries [1].

According to Mateescu, these were [2]:

1) Small plants with capacity of up to $14 \mathrm{~m}^{3}$, simple design, biogas production $3 \mathrm{~m}^{3}$ / day;

2) Average capacity plants, capacity $30-50 \mathrm{~m}^{3}$, simple design;

3) Larger capacity plants- over $500 \mathrm{~m}^{3}$.

Unfortunately, the interest for this sector was significantly reduced in the 1990s. Mateescu explains this break in development due to the socio-economic and political situation in Romania, as well as due to a lack of know-how. This lack of interest resulted in a lack of engagement in the sector. Not only there were no new investments in the field, no maintenance work was carried out for the existent capacities.
The research in this field was also aborted by the Romanian academics but also by the business sector.

Until 2007 there were few incentives for foreign companies with tradition in the biogas field to enter the Romanian market. Baran [3] argued that it is up to the companies to improve the biochemical processes in anaerobic digesters in order to reach a high biogas yield. Only this way plants can be economically efficient considering the current energy prices.

In order to break this vicious cycle, 2008 the Romanian Government initiated a support scheme for the generation of electricity from renewable energy sources. Electricity from biogas was also covered by the supporting legislation. The support mechanism was still under development and no relevant investments occurred in the field until 2011. The Table I presents the development of the biogas sector in the past 4 years:

\begin{tabular}{lllll}
\multicolumn{5}{c}{ TABLE I: ON-GRID BIOGAS PLANTS IN ROMANIA } \\
\hline & $\mathbf{2 0 1 1}$ & $\mathbf{2 0 1 2}$ & $\mathbf{2 0 1 3}$ & $\mathbf{2 0 1 4}$ \\
\hline Nr. of plants & 1 & 3 & 5 & 10 \\
\hline Installed capacity(MWel) & 1,9 & 5 & 6,9 & 12,1 \\
\hline Power generation (MWh) & 13.231 & 18.610 & 35.995 & 39.655 \\
\hline Source: Transelectrica, ANRE & & & &
\end{tabular}

\section{ECONOMIC POTENTIAL}

In order to prove the first hypothesis, we took a closer look at the biogas production potential. 2006 two traditional Romanian R\&D institutes [4] evaluated Romania's annual production potential at approximately 1,18 billion $\mathrm{m}^{3}$ of biogas / year. Romania's heat generation potential from biogas amounts according to their study to approximately $14.800 \mathrm{TJ} /$ year and the electricity generation potential at 0,35 million (Mil.) TOE / year. Romania's Energy Strategy presents the E-RES production potential from biogas at 0,58 Mil. TOE / year. We made our own measurements considering only organic waste as potential substrate.

Romania has, according to the National Bureau of Statistics 13,3 Mil. hectares (ha) of agricultural land; another 6,4 Mil. ha are forests. Of the agricultural land 8,3 Mil. ha represent arable land, 0.3 Mil. ha permanent pasture, 4.5 Mil. ha are meadows and 0,2 Mil. ha are classified as vineyards and orchards.

TABLE II: BIOGAS POTENTIAL FROM AgRICULTURAL WASTE

\begin{tabular}{|c|c|c|c|c|c|}
\hline & Wheat & Maize & Sugar beat & Oilseeds & Total \\
\hline Main agricultural products (Tsd. t) & $8.709,9$ & $11.720,2$ & 675 & $2.612,8$ & 23.718 \\
\hline Waste (\% of the Production) & 0,25 & 2 & 0,2 & 1,2 & \\
\hline Waste Tsd. t & $2.177,48$ & $23.440,4$ & 135 & $3.135,36$ & $\mathrm{XXX}$ \\
\hline Dry matter (\%) & 0,85 & 0,86 & 0,18 & 0,13 & \\
\hline Organic materials of the DM (\%) & 0,9 & 0,72 & 0,81 & 0,85 & \\
\hline Biogas (m³/t OMDM) & 350 & 820 & 675 & 710 & \\
\hline Biogas energy potential $\left(\mathrm{Nm}^{3}\right)$ & 583 Mil. & 11.901 Mil. & 13,2 Mil. & 246 Mil. & 12.744 Mil. \\
\hline Biogas energy / year (MWh) & 3.497 .414 & 71.396 .056 & 79.700 & 1.475 .613 & 76.448 .783 \\
\hline Installed capacity MW & 186 & 3.798 & 4 & 78 & 4.066 \\
\hline
\end{tabular}

Source: Ministry of Agriculture and Rural Development, Probiopol, own calculations. 
The main agricultural products are maize (2,5 Mil. ha), wheat ( 2 to 2,5 Mil. ha) and oilseeds (1,3 Mil. ha). The average yields of maize is 2-4 t/ ha, and for wheat between 1.5 and $3 \mathrm{t} / \mathrm{ha}$ - a relatively low level in Europe. Table II shows the biogas potential from agricultural waste. In the calculations of the potentials, we assume that ca. 0,6 Mil. MWh - which would require an installed capacity of 32 megawatts - can be produced from $100 \mathrm{Nm}^{3}$ gas. "The main source of agricultural waste that can be used in the biogas sector is maize waste. Currently, the waste is burned, buried or used as inferior food. However, these figures may offer only a theoretical dimension of the biogas production potential from vegetable waste. In reality, there are several reasons why this potential will never be used throughout.

The main reasons for the deviation are the position of the surfaces as well as the available machinery. These generate costs of collection, transport and storage that can make biogas projects unfeasible. The matter of few existing big agricultural companies should be addressed here as well. It can be difficult for a plant operator not active in the agricultural sector to bring together the necessary feedstock for a medium-sized plant.

Manure is a much more attractive source for biogas, which is available through the whole year in constant amounts (and therefore must not be stored; vegetable waste is available mainly in summer and autumn). Table III shows the biogas potential resulting from husbandry.

The value of this estimation is relative, depending on the concentration of animals. Biogas applications can be interesting for large and medium sized farms, where the manure collection is organised accordingly. For that, and the fact that there are comparatively few such farms in Romania, probably only half of the theoretic potential is technically available.

Other substrate sources for the biogas production are in the food processing industry, sewage plants and waste deposits.

The food processing industry generates a significant volume of organic waste in the manufacture of foods for human and animal consumption. Industrial food waste includes fresh fruit and vegetable juice, peels, seeds and parts, draff (spent brewery grain), milk and dairy materials, seafood products, and other food products rejected in the manufacture of processed foods. Although these materials generally have high biogas yields, the availability of alternative disposal methods to landfills, such as selling it to farmers and animal husbandry operations for use as livestock feed supplements, makes it more expensive to obtain for energy production than other sources [5]. On the other hand, almost every kind of food production process requires both electricity and heat or cold for thermal treatment or storage. Electricity is required for pumps, ventilation, mixing and conveying equipment, etc. The thermal processing includes both high temperatures for operations such as pasteurization, boiling and evaporation as well as low temperatures.

According to Eurostat, the food processing industry produces yearly almost 900 thousand tonnes of waste. The waste can be used directly as solid biomass or as feedstock for the production of biogas. The amount of organic waste per food sector depends on the processed raw material and purification technologies used. The gained biogas can be processed further in tri-generation plants. Especially attractive industries are the sugar processing industry, the beer manufacturers and the dairy industry. The collected potential of these industrial branches exceed a production capacity of $200 \mathrm{MWel}$.

Romania has over 500 sewage treatment plants. Ca. $90 \%$ of the resulted sewage sludge are stored within them, $9 \%$ are brought to the landfill and under $1 \%$ is used in agriculture. A small part of the existing wastewater treatment plants uses the sewage gas for electricity and heat production. Currently, only one plant has a grid-connected gas installation.

According to the Romanian Environmental Protection Agency, the yearly sludge production is about 150.000 tonnes dry matter. Experts estimate the potential biogas production from sewage sludge to $90 \%$ (organic) x $1,000 \mathrm{~m}^{3} / \mathrm{t}$ dry matter. That is as much as 135 Mil. cubic meters of biogas with $60 \%$ $\mathrm{CH} 4$ content. In the end, $81 \mathrm{Mil} . \mathrm{m}^{3} \mathrm{CH} 4$ remains from which you could produce 0,8 Mil. MWh at a capacity of exceeding $40 \mathrm{MWel}$. Many plants are suitable for the implementation of biogas projects. Billions of euros are available for operators of sewage treatment plants and distribution networks from EU-funding programs. A part of these funds could be used for E-RES production as well.

The fact that a large proportion $(50-65 \%)$ of household waste is biodegradable opens great opportunities for energy recovery. According to Eurostat, the yearly amount of household waste lies ca. 6,2 Mil. tonnes. To comply with EU-Standards many old landfills had to be closed and the existing landfills are relatively new. However, the landfill gas issue will gradually rise. After 3-4 years of operation of a landfill, a deposit gas plant may be operated efficiently.

Experts expect the demand for such systems to rise.

TABLE III: BIOGAS POTENTIAL HUSBANDRY

\begin{tabular}{|c|c|c|c|c|c|c|}
\hline & Cattle & Horses & Sheep and goats & Swine & Poultry & Total \\
\hline $\mathrm{Nm}^{3}$ Biogas/1000 kg living animals/ day & 3,05 & 3,31 & 4,15 & 2,62 & 6,21 & \\
\hline Number of animals & 2.200 .000 & 605.000 & 11.300 .000 & 4.100 .000 & 70.000 .000 & \\
\hline Medium weigh(kg) & 344 & 412 & 24 & 110 & 2 & \\
\hline Total weigh (t) & 756.800 & 249.260 & 271.200 & 451.000 & 161.000 & \\
\hline Biogas production/ Day $\left(\mathrm{Nm}^{3}\right)$ & 2.308 .240 & 825.051 & 1.125 .480 & 1.181 .620 & 999.810 & 6.440 .201 \\
\hline Biogas production/ year $\left(\mathrm{Nm}^{3}\right)$ & 842 Mil. & 301 Mil. & 410 Mil. & 431 Mil. & 364 Mil. & 2.350 Mil. \\
\hline Biogas energy / year (MWh) & 5.054 .035 & 1.806 .500 & 2.464.308 & 2.587 .230 & 2.189 .146 & 14.101 .219 \\
\hline Installed capacity MW & 268,83 & 96,09 & 131,08 & 137,62 & 116,44 & 750,06 \\
\hline
\end{tabular}

Source: Ministry of Agriculture and Rural Development, Probiopol, own calculations 
If we assume that $1 \mathrm{~m}^{3}$ can generate $6 \mathrm{kWh}$ and that there are collected yearly 3.2 Mil. tonnes biodegradable waste with a gas production of $120 \mathrm{~m}^{3}$ of biogas / $\mathrm{t}$, the annual biogas production potential is estimated at $384 \mathrm{Mil} . \mathrm{m}^{3}$. This results in 2.3 Mil. MWh. The potential for total installable power is then about 123 megawatts.

Aside from the threats generated by a still fragmented, developing agricultural and husbandry sector, we consider the first hypothesis proven by the identified facts regarding production potentials.

\section{LEGAL FRAMEWORK}

Worldwide, the governments of many developed countries encourage the use of energy from biomass (or other renewable sources) as alternative energy sources through supporting policies and financial schemes. By increasing the share of energy from biomass in the energy mix, policy makers also aim to generate economic added value, especially in terms of increasing the number of jobs, improving energy security, income generation through job creation and export growth, in addition to environmental benefits [6]. European Union countries are among them: encouraging the use of alternative energy sources is one of the main objectives of the EU.

In Romania's case, the promotion of renewable energy production is ensured by a combined system relying on compulsory quotas and green certificates. Law Nr. 220/2008 regulates the promotion mechanism for the production of electricity from renewable sources.

The law obliges all electricity suppliers to meet annually prior set quotas of E-RES in the energy mix. This means that a certain percentage of the amount of electricity supplied to the end consumer should come from renewable sources. The E-RES producer receives for every MWh feed into the system next to the market price for electricity (when he trades the energy) a certain amount of green certificates - for biogas up to 3 certificates. The E-RES producer will get 2 certificates for biogas and 1 certificate for sludge or deposit gas for 20 years. Additionally he can get 1 certificate if the electricity is produced in cogeneration. The supplier reaches the set quota by purchasing green certificates. The remuneration for the energy producer consists of the current price for electricity and an additional compensation received in the traded green certificates. The certificates may be traded on a specialised market in the price range $€ 27-55$ /piece + Euro-inflation.

The average electricity price for E-RES producers in 2013 was $35,3 € / \mathrm{MWh}$. The average price for a certificate in 2013 was $€ 44,71$. The current minimum value for certificates is 29,3 $€ / \mathrm{MWh}$ and the maximum value 59,6 $€ / \mathrm{MWh}$. A biogas producer using cogeneration will earn between 123,9€ / MWh (worst case scenario) and 214,1 € / MWh (best case scenario), numbers which place Romania among the more active supporters of biogas in Europe.

The feedback of the business community determined us to analyse the consistency of the support mechanism. For amending the support system in Romania, 14 Government Decisions, 3 Government Emergency Ordinances, 2
Government Ordinances and 4 laws were issued since 2008. In 2013 and 2014 legislative changes have led among other things to the reduction of the number of certificates issued for wind power or photovoltaics. These measures do not directly affect all E-RES sectors, but have been blamed for generating instability. They set a new legal precedent, just months after implementing other legislative changes that affects new and existing projects. The former legislation established annual quotas of green certificates until 2020. These quotas will now be set annually, thus reducing the predictability of the system. Also the mandatory quota for 2014 has been reduced substantially from the initial rate. In a system where the price of certificates is determined by supply and demand, these measures affect both new investors and those already active in the market.

The hope of potential investors is however strongly related to a part of the law not put into practice yet. Current law specifies the possibility of owners of plants smaller than 10 MW to opt for a feed in tariff. This scheme - although expected to be financially less attractive - is supposed to be easier from a bureaucratic point of view and would allow investors better conditions for drafting long-term business plans.

The second formulated hypothesis could hereby not be proven or dismissed. A closer look to the results of the business community consultation will give us further advice.

\section{Business Practices AND Business MODELS}

In order to assess the current market situation, our research group conducted in the period October 2013 - March 2014 interviews with 26 experts from the E-RES field, 10 of whom are active exclusively in Romania, 15 active in Romania and other countries, especially in Germany — the European leader in the biogas field.

In the case of energy producers from biogas, their success depends on the available natural resources as well as on the support mechanisms put into place. As long as grid parity costs are not reached, supporting mechanisms are indispensable. According to the questioned experts, the political factor significantly influences the decisions taken in renewable energy companies. The legislative changes that took place in Romania in 2012-2014 led to a predominantly negative perception of the external environment. Specifically, $42 \%$ of the experts surveyed consider the current business environment (March 2014) of Romania as uncertain and lacking in opportunities, $33 \%$ risky, but full of investment opportunities and only $25 \%$ full of long-term and short-term investment opportunities.

Market perception depends a lot on the source of renewable energy the expert is interested in. While wind and solar energy experts were rather pessimistic about market development in Romania, only $14 \%$ of the experts engaged in the biogas sector consider the Romanian investment environment as unsafe and lacking in opportunities.

The second hypothesis formulated remains hereby unproven. 
TABLE IV: BIOGAS BUSINESS MODELS

The biogas plant owner is...

The biogas plant operator...

an investor / a group of investors / an investment fund

the plant operator

the district heating company

the heat consumer

the local / regional electricity distributor

the electricity consumer captures landfill gas or sewage gas

neutralizes and eliminates organic waste resulting

from its core business

neutralizes and eliminates organic waste arising from a client's activity

purchases fodder / energy plants to use as a substrate cultivates fodder / energy crops to use as a substrate

stores biogas to convert it at a later time to electricity in order to balance the electricity network

upgrades biogas to feed it into the natural gas network

upgrades biogas to store as compressed natural gas (CNG)

converts biogas to power

converts biogas to heat

converts biogas to power and heat by cogeneration uses the produced electricity to meet its own needs uses the produced heat to meet its own needs sells electricity to the regional grid operator sells heat to the district heating company sells electricity to a trading company sells electricity to a third party (consumer) sells heat to a third party (consumer) sells green certificates to a regional network operator

sells green certificates to a trading company

sells green certificates to a energy producer from fossil sources

uses certificates to compensate for its own obligation to purchase green certificates
Siegel identified 3 main drivers for entering the green business sector [7]: gaining competitive advantage, the improvement of the company's image and government regulation compliance. The polarization of ecological themes is relatively low in Romania, a fact that doesn't encourage companies directly to "act green". The environmental legal framework is still under construction and law enforcement is currently less developed in Romania than in other EU-countries. Romania negotiated a longer transition period regarding waste management regulations. It is interesting to observe if these factors will gain more importance for the future, especially in case of regulatory sharpening and a slight shift in public opinion, like for instance in the case of many Western European Countries. The question of competitive advantage remains open.

Analysing the chance of gaining competitive advantage, Mitchell [8] stresses the opportunity of continuing business model innovation as a parallel way to outperform the competition.

Companies need to adopt business models that relate to irresistible forces in a flexible way. Companies need to create processes for making innovations and improvements.

In order to analyse the development of business models in the biogas field, we split these into components according to the components mentioned by market participants in open interviews conducted. The identified components of the business models described by companies engaged in the biogas field are available in Table IV.

According to the interviewed experts, in the business models put in practice or planed to be used today, the plant owner is most often an investor acting also as the operator of the plant. Feedstock is rather bought or provided by the energy customers (the investor operates like an ESCO). The biogas is converted to heat and power by cogeneration. Power is fed into the regional grid and is (as also the green certificates are) sold to a regional network operator.

Interviewed about the future development of the sector, the experts expect a shift to decentralised energy supply by 2020 and after. The biogas plant owners of tomorrow - still mainly investors and groups of investors - will act as local energy suppliers (12 quotations). Next to the use in CHP-units, several other business model components from the table above were quoted.

The experts also expect more companies engaged in other business fields to enter the biogas sector in order to neutralise and eliminate the organic waste resulting from their core business $(10 \mathrm{q})$. In their case, the resulted electricity and gained green certificates will be sold to trading companies (11 q, 10 q).

The expected introduction of the feed-in-tariffs for projects smaller than $10 \mathrm{MW}$ will for sure encourage these new types of biogas entrepreneurs although current business models will stay in practice. The third hypothesis is hereby partially proven.

\section{CONCLUSIONS AND OUTLOOK FOR THE ROMANIAN BIOGAS SECTOR}

In spite of the low yields in agriculture and the high polarisation of agricultural fields and livestock, Romania is characterised by a high natural potential for biogas production. Next to the feedstock available in agriculture and in husbandry, industrial waste of the food processing industry, municipal waste deposits and sewage sludge plants produce generous amounts of organic waste usable in biogas energy production.

The changes to the legislation regarding E-RES support although these affected the biogas sector less than other sectors - fiscal changes (introduction of a tax for special constructions) and cost increases in big consumers' but also household customers' electricity bills contributed according to the interviewed experts plenty to this lack of development in the Romanian biogas sector but are not the only reasons for its slow pace.

These changes in the external environment are already reflected in the companies' business models, and especially in the future trends of their core focuses. In future, the biogas sector is expected to be strongly connected to the need of own waste neutralization. The introduction of a feed-in tariff, rather than the green certificates support system in place today, 
should contribute to more entrepreneurial action in the field, especially from companies engaged in other core businesses. Experts also expect decentralised energy supply models to develop.

In terms of technologies, biogas is expected to be further used in combined heat and power plants (CHP plants) with very high degrees of efficiency. Within short and medium terms, prior unused organic waste from landfills and sewage treatment stations will definitely be used for energy generation purposes. Within medium term the food processing industry is expected to become more engaged in the sector, implementing CHP-units where the waste heat can also be utilised in downstream systems to generate additional power, for heating and drying or in the operation of refrigerators.

Further technologic development like the use of biogas in fuel cells could conduct to new business models in the long run. Feed-in of prior treated biogas into national natural gas grid or compressing it for later use are according to the interviewed experts not feasible options for the Romanian market. The biogas sector is expected to develop at a slow pace independently of the development of the legal framework for supporting the field. A faster pace depends on the general context regarding the renewable field. A further expansion of the E-RES sector will though require a period of adjustment and financial and mental efforts from energy producers, suppliers and consumers.

\section{REFERENCES}

[1] A. Ofiteru, M. Adamescu, and F. Bodescu. (2008). Biogas and biodiesel market prospects in Romania. Big-East Project: Forum Newpower. [Online]. pp. 28-24. Available: http://www.big-east.eu/downloads/downloads.html

[2] C. Mateescu, G. Băran, and C. A. Băbuţanu, "Opportunities and barriers for development of biogas technologies in Romania,' Environmental Engineering and Management Journal, vol. 7, no. 5, pp. 603-607, 2008.

[3] G. Băran, Achievements and Perspectives in Biogas Industry (in Romanian), Bucharest, Romania: Printech Press, 2008.

[4] INL, ICEMENERG. (2006). Planul naţional de acţiune în domeniul energiei din surse regenerabile (PNAER). [Online]. Available: http://www.icemenerg.ro/PROSERV/PNAER.htm
[5] M. Schiller, "Food waste biogas development," Petroleum Accounting and Financial Management Journal, vol. 32, no. 1, pp. 70-89, 2013.

[6] J. Domac, K. Richards, and V. Segon. (2008). Old fuel for modern times - Socio economic drivers and impacts of bioenergy use. Renewables World News. [Online]. Available: http://www.task29.net/assets/files/reports/Domac_Richards_Segon_2 005.pdf

[7] J. Siegel, C. Nedler, and N. Hodge, Investing in Renewable Energy: Making Money on Green Chip Stocks, Hoboken: John Wiley and Sons, 2008.

[8] D. Mitchell and C. Coles, "The ultimate competitive advantage of continuing business model innovation," The Journal of Business Strategy, vol. 24, no. 5, pp. 15-21, 2013.

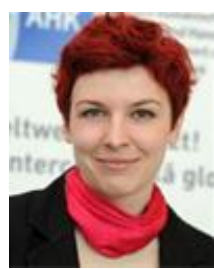

Roxana Clodnițchi was born in Arad in 1983 and graduated in 2006 with a BSc degree in business administration from the Bucharest University of Economic Studies, Romania. Then she obtained a MA-Diploma in The Management of International Relations and Community Affairs with the Babes Bolyai University of Cluj Napoca, Romania. Since 2012 she became a $\mathrm{PhD}$ candidate with the University of Economic Studies Bucharest.

She started her professional activity in 2007 with the European Commission as a blue book stagiaire in DG Communication and continued with the German Chamber of Commerce in Romania where she works since 2008 as a business consultant and as a project coordinator since 2010 for the green tech plat from www.econet-romania.com.

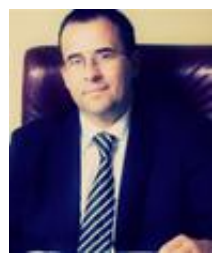

Adrian Dumitru Tanțău has a $\mathrm{PhD}$ degree in electronic engineering with the Bucharest Politehnic University and one in management with the Bucharest University of Economic Studies.

$\mathrm{He}$ is the dean of the Faculty for Business Administration in Foreign Languages, Bucharest University of Economic Studies, a coodinator of the MBA Programs, "Entrepreneurship and Business Administration in Energy," and "Unternehmensführung und Innovationsmanagement" as well as of several research projects. So far he published 20 books and over 60 articles.

$\mathrm{He}$ is a honorary member of the Romanian National Committee for the World Energy Council, European Foundation for Entrepreneurship Research, the chairman of the Society for Business Excellence and a member of several associations and administration councils. 